Linguista: Jurnal IImiah Bahasa, Sastra, dan Pembelajarannya

Vol.3, No.2, Desember 2019, hal 145-152

ISSN (print): 2579-8944; ISSN (online): 2579-9037

Avaliable online at: http:/le-journal.unipma.ac.id/index.php/linguista

\title{
Penerapan Model Pembelajaran Problem Based Learning dengan Multimedia untuk Meningkatkan Kemampuan Menulis Puisi Siswa
}

\author{
Anik Kusrianti dan V. Teguh Suharto \\ Universitas PGRI Madiun, JI. Setiabudi No. 85 Madiun, Indonesia \\ e-mail: aka.antie@gmail.com; suharto_teguh@yahoo.com
}

\begin{abstract}
Abstrak
Penelitian ini bertujuanuntuk mendeskripsikan penerapan Problem Based Learning dengan multimedia dalam pembelajaran menulis puisi dan untuk menjelaskanhasil belajar menulis puisi siswa kelas VIII SMP Negeri 1 Pangkurmenggunakan model pembelajaran Problem Based Learning dengan multimedia. Jenis penelitian ini adalah penelitian tindakan kelas yang terdiri dari dua siklus. Subjek dalam penelitian ini adalah siswa kelas VIII G SMP Negeri 1 Pangkur. Hasil penelitian menunjukkan adanya peningkatan. aktifitas kegiatan siswa dari siklus I dengan persentase $71,88 \%$ ke siklus II dengan persentase $87,50 \%$ dan apresiasi menulis puisi siswa mengalami peningkatan pada siklus I dengan persentase $71,17 \%$ dan meningkat pada siklus II sebesar $83,75 \%$. Kedua dapat meningkatkan hasil belajar menulis puisi siswa yang menyangkut aspek kognitif, afektif, dan psikomotor dengan hasil belajar berikut ini (1) prestasi belajar siswa tuntas $87,50 \%$ (2) $87,50 \%$ siswa mampu menghasilkan puisi dengan kualifikasi baik, (3) $85,25 \%$ siswa memiliki tingkat keaktifan belajar baik, (4) 83,75\% siswa memiliki apresiasi menulis puisi baik. Dengan demikian, dapat disimpulkan bahwa dengan menerapkan model pembelajaran Problem Based Learning dengan Multimedia dapat meningkatkan kemampuan menulis puisi siswa kelas VIII SMP Negeri 1 Pangkur Kecamatan Pangkur Kabupaten Ngawi.
\end{abstract}

Kata kunci: Problem Based Learning; Multimedia; Menulis Puisi.

\section{The Application of Problem Based Learning with Multimedia to Improve the Ability Student to Write Poetry}

\begin{abstract}
This study aims to describe the application of Problem Based Learning with multimedia to write poetry and to explain the learning outcomes of writing poetry for the eighth grade students of SMP Negeri 1 Pangkur using Problem Based Learning with multimedia. This type of research was classroom action research consisting of two cycles. Each cycle was carried out by planning procedures, implementing actions, observing and reflecting. The subjects in this study were class VIII G SMP Negeri 1 Pangkur. The results show the students activities from the first cycle with a percentage of $71.88 \%$ increase in the second cycle with a percentage of $87.50 \%$ and the appreciation of writing poetry students increases in the first cycle with a percentage of $71.17 \%$ and increases in the second cycle by $83.75 \%$. Secondly, it can improve student learning outcomes in writing poetry related to cognitive, affective, and psychomotor aspects with the following learning outcomes (1) complete student achievement $87.50 \%$ (2) $87.50 \%$ students are able to produce poetry with good qualifications, (3 ) $85.25 \%$ of students have a good level of learning activeness, (4) $83.75 \%$ of students have an appreciation of writing good poetry.
\end{abstract}


Thus, it can be concluded that by applying the Problem Based Learning model with Multimedia can improve the ability to write poetry for eighth grade students of SMP Negeri 1 Pangkur, Pangkur District, Ngawi Regency. The purposes of this research are to describe and explain: (1) Islamic boarding school ideology by using Micro text analysis (textual analysis), Fairclough critical analysis model in Ahmad Fuadi's Negeri 5 Menara. (2) Islamic boarding school ideology by using Meso text analysis (Discourse practice analysis, Fairclough critical discourse analysis model in the novel Negeri 5 Menara,. (3) Islamic boarding school ideology by using Macro text analysis (Sociocultural analysis) in the novel Negeri 5 Menara. This research used analytical descriptive method with Islamic boarding school ideology in the novel Negeri 5 Menara as the research object. Documentation technique of data collection was used in this research. Technique of analyzing data used was flow model by Miles and Huberman. Data source were derived from 423 pages novel texts of Ahmad Fuadi's Negeri 5 Menara. The results show that: (1) There have been ideologies applied in Islamic boarding school. Islamic terms usage in the novel shows that in some islamic behaviors are also taught in the boarding school,

(2) the analysis shows that there has been description and introduction to patterns of Islamic boarding school which hasn't previously been recognized by many people. (3) The real story of the author who tells all sorts of efforts and obstacles in accomplishing his dreams.

Keywords: Problem Based Learning; Multimedia; Writing Poetry Skill.

\section{Pendahuluan}

Dalam Kurikulum 2013 pembelajaran Bahasa Indonesia digunakan sebagai sarana untuk mengembangkan kemampuan dan keterampilan menalar. Kemampuan menalar peserta didik Indonesia masih sangat rendah. Hal ini diketahui dari studi Trends in International Mathematics and Science Study (TIMSS) tahun 2011, hanya lima persen peserta didik Indonesia yang mampu memecahkan persoalan yang membutuhkan pemikiran, sedangkan sisanya hanya sampai pada level menengah, yaitu memecahkan persoalan yang bersifat hapalan. Untuk itu, pembelajaran bahasa Indonesia merupakan salah satu solusi, yaitu dengan menjadikan bahasa sebagai penghela ilmu pengetahuan dan pembelajaran berbasis teks.Pembelajaran bahasa Indonesia diberikan pada peserta didik bertujuan untuk melatih peserta didik terampil berbahasa dengan menuangkan ide dan gagasannya secara kreatif dan kritis.

Pembelajaran menulis puisi merupakan bagian dari pembelajaran bahasa Indonesia. Menulis merupakan suatu kegiatan yang produktif dan ekspresif. Menurut Tarigan (2008: 4), dalam kehidupan modern ini keterampilan menulis sangat dibutuhkan. Keterampilan menulis merupakan ciri dari orang yang terpelajar atau bangsa yang terpelajar. Sebuah puisi adalah sebuah struktur yang terdiri dari unsur-unsur pembangun. Unsur-unsur pembangun tersebut dinyatakan bersifat padu karena tidak dapat berdiri sendiri tanpa mengaitkan unsur yang satu dengan unsur yang lainnya. Unsur-unsur dalam puisi bersifat fungsional dalam kesatuannya dan juga bersifat fungsional terhadap unsur lainnya (Waluyo, 1995: 25).

Dalam perspektif pendidikan, seni menulis puisi termasuk seni sastra yang dipandang sebagai salah satu instrumen untuk memberikan keseimbangan antara intelektualitas dan sensibilitas, antara pikiran dan kepekaan rasa. Puisi merupakan karya sastra yang bernilai tinggi dimana di dalamnya terdapat berbagai macam unsur. Puisi terdiri atas dua unsur pokok yaitu struktur fisik dan struktur batin. Kedua bagian puisi 
tersebut terdiri atas unsur-unsur yang saling mengikat keterjalinan dan unsur tersebut membentuk totalitas makna yang utuh. Struktur fisik puisi terdiri atas diksi, pengimajian, kata konkrit, majas, verifikasi, dan tipografi puisi. Sedangkan struktur batin puisi terdiri atas tema, nada, perasaan, dan amanat.

Terkait dengan pembelajaran bahasa Indonesia di sekolah, pembelajaran menulispuisi perlu mendapatkan perhatian serius. Hal ini berdasarkan kenyataan dan pengamatan peneliti bahwa pengajaran menulis puisiyang dilakukan sebagian besar guru masih berorientasi pada pembelajaran yang bersifat teoretis, dan kurang mendorong tumbuhnya kreativitas dalam diri peserta didik. Pengajaran menulis puisi yang dilaksanakan di sekolah-sekolah dipandang belum sepenuhnya bisa memenuhi tujuan pendidikan nasional. Pengajaran menulis puisi dianggap hanya sekadar memenuhi target kurikulum dan tidak menukik pada permasalahan apresiasi sastra lebih mendalam.Kegiatan mengakrabi puisi perlu ditumbuhkan secara terus-menerus dan sungguh-sungguh sehingga tumbuh pengertian, penghargaan, kepekaan pikiran kritis, dan kepekaan perasaan yang baik terhadapnya. Dengan demikian, karya puisi nantinya akan dijadikan bagian hidup bagi para peserta didik yang diharapkan mampu memenuhi kebutuhan rohaniahnya.

Pembelajaran menulis puisi di kelas VIII SMP Negeri 1 Pangkur Kecamatan Pangkur Kabupaten Ngawi hingga saat ini dianggap belum menyentuh substansi serta mampu mengusung misi utamanya, yaitu memberikan pengalaman bersastra (apresiasi dan ekspresi) kepada para peserta didik. Akibatnya, capaian tujuan pengajaran menulis puisi dinilai masih jauh dari harapan.Ada beberapa faktor yang mempengaruhi hasil belajar peserta didik dalam pembelajaran bahasa Indonesia khususnya dalam menulis puisi, diantaranya adalah guru harus menguasai prinsip-prinsip pembelajaran, pemilihan dan penggunaan media pembelajaran, pemilihan dan penggunaan metode mengajar, keterampilan menilai hasil belajar peserta didik, serta memilih dan menggunakanstrategi atau pendekatan pembelajaran.

Berdasarkan observasi yang dilakukan di kelas VIIISMP Negeri 1 Pangkur Kecamatan Pangkur Kabupaten Ngawi tahun terdapat beberapa permasalahan dalam pembelajaran menulis puisi. Pertama, peserta didikmenganggap bahwa kegiatan menulis puisi adalah kegiatan yang sulit. Kedua, peserta didik kurang memiliki minat dan motivasi dalam menulis puisi. Ketiga, kurangnya sikap kooperatif di kalangan peserta didik dalam proses pembelajaran. Keempat, nilai mata pelajaran bahasa Indonesia kelas VIII belum mencapai KBM (Ketuntasan Belajar Minimal) sebesar 75. Kelima, guru masih sering menggunakan metode yang konvensional dalam proses pembelajaran. Uno dan Nurdin (2015: 106), menyampaikan bahwa pembelajaran konvensional adalah pembelajaran pada umumnya yang dilakukan oleh guru. Pembelajaran yang masih berpusat pada guru (teacher centered) dengan bercerita atau berceramah dan hanya dilakukan dengan teori sesuai dengan buku paket.

Berdasarkan permasalahan di atas maka peneliti menerapkan model pembelajaran Problem Based Learning dengan Multimediasebagai solusinya. Menurut Ngalimun (2016: 117), Problem Based Learning merupakan salah satu model pembelajaran inovatif yang dapat memberikan kondisi belajar aktif kepada peserta didik. Problem Based Learningadalah pendekatan pembelajaran yang menggunakan masalah nyata sebagai konteks, sehingga peserta didik dapat belajar berpikir kritis dalam melakukan pemecahan masalah yang ditujukan untuk memperoleh pengetahuan atau 
konsep yang esensial dari bahan pelajaran (Suhana, 2014: 70). Ada 5 fase (tahap) yang harus dilakukan untuk mengimplementasikan model pembelajaran Problem Based Learning (Suhana, 2014: 42), sebagai berikut; Fase 1 Mengorientasi siswa pada masalah, Fase 2 Mengorganisasi siswa untuk belajar, Fase 3 Membimbing penyelidikan individu dan kelompok, Fase 4 Mengembangkan dan menyajikan hasil karya, Fase 5 Menganalisis dan mengevaluasi proses pemecahan masalah.

"Multimedia is the use of several media to present information. Combinations may include text, graphics, animation, pictures, video, and sound. Educators have been using multimedia for years" (Ivers dan Barron, 2010: 2). Multimedia adalah penggunaan komputer untuk menyajikan dan menggabungkan teks, suara, gambar, animasi, audio, dan video dengan alat bantu (tool) dan koneksi (link) sehingga pengguna dapat melakukan navigasi, berinteraksi, berkarya dan berkomunikasi. Di dunia pendidikan, multimedia dapat digunakan sebagai media pembelajaran, baik di dalam kelas maupun secara sendiri-sendiri atau otodidak.

\section{Metode Penelitian}

Jenis penelitian ini adalah Penelitian Tindakan Kelas Partisipan yaitu penelitian tindakan (action research) yang melibatkan peneliti, guru muatan pelajaran bahasa Indonesia, dan siswa kelas VIII SMP Negeri 1 Pangkur Kecamatan Kwadungan Kabupaten Ngawi. Penelitian tindakan kelas partisipan ini dilakukan dengan tujuan memperbaiki mutu praktik pembelajaran di kelas.Penelitian tindakan kelas diartikan sebagai proses pengkajian masalah pembelajaran di dalam kelas melalui refleksi diri dalam upaya untuk memecahkan masalah dengan cara melakukan berbagai tindakan yang terencana dalam situasi nyata serta menganalisis setiap pengaruh dari perlakuan tersebut (Sanjaya, 2009: 26).

Subyek yang diteliti yaitu siswa dan guru Bahasa Indonesia kelas VIIIG SMPNegeri 1 Pangkur. Teknik pengumpulan data dilakukan dengan observasi, tes, angket, wawancara, dan dokumentasi. Instrumen penelitian tindakan kelas ini menggunakan pedoman observasi, lembar evaluasi menulis puisi, rubrik penilaian menulis puisi, angket, instrument wawancara, dan dokumen. Prosedur penelitian menggunakan alur penelitian kelas model Kemmis \& Mc. Taggart. Indikator kinerja penelitian ini adalah; 1) Prestasi belajar $80 \%$ siswa mendapat nilai $\geq 75$, 2) $80 \%$ siswa mampu menghasilkan puisi dengan kualifikasi baik, 3) $80 \%$ siswa memiliki tingkat keaktifan belajar baik, 4) $80 \%$ siswa memiliki apresiasi menulis puisi baik. Teknik analisis data penelitian ini menggunakan analisis data kualitatif: Miles \& Huberman dan analisis data kuantitatif.

\section{Hasil dan Pembahasan}

Secara umum hasil penelitian tindakan kelas yang telah dilaksanakan tergambar pada tabel 1.

\section{A. Implementasi Model Pembelajaran Problem Based Learning Dengan Multimedia Dalam Pembelajaran Menulis Puisi}


Penelitian pengamatan penerapan model pembelajaran Problem Based Learning dengan Multimedia dalam pembelajaran menulis puisi siswa kelas VIII SMP Negeri 1 Pangkur Kecamatan Pangkur Kabupaten Ngawi.

1. Aktivitas Pembelajaran

Dari tabel 1di atas menunjukkan bahwa rata-rata keaktifan kegiatan siswa dari siklus I ke siklus II naik sebesar $8 \%$. Dengan demikian dapat disimpulkan bahwa dengan menggunakan model pembelajaran Problem Based Learning dengan Multimedia dapat menarik perhatian siswa dalam kelas dan membuat siswa lebih aktif selama kegiatan belajar mengajar berlangsung. Hal ini sejalan dengan pendapat Suhana (2014: 42), bahwa model pembelajaran Problem Based Learning dengan Multimedia dapat meningkatkan motivasi belajar siswa, mendorong kemampuan siswa untuk melakukan pekerjaan penting, meningkatkan kemampuan pemecahan masalah, membuat siswa menjadi lebih aktif dan berhasil memecahkan masalah yang kompleks, meningkatkan kolaborasi, mendorong siswa untuk mengembangkan dan mempraktikkan keterampilan komunikasi, meningkatkan keterampilan siswa dalam mengelola sumber pembelajaran.

2. Hasil Belajar

Dari Tabel1 dapat diketahui siswa yang tuntas di kelas VIII G pada siklus I sebesar $71,88 \%$, siklus II sebesar87,50\%. Kemudian untuk siswa yang tidak tuntas mengalami penurunan dari siklus I sebesar28,12\% dan siklus II sebesar12,50\%. Dengan demikian dapat disimpulkan bahwa pembelajaran dengan model pembelajaran Problem Based Learning dengan Multimedia pada materi menulis puisi dapat meningkatkan hasil belajar siswa karena berdasarkan pendapat Hamalik (2004: 49), menyatakan bahwa hasil belajar adalah sebagai tingkat penguasaan yang dicapai oleh siswa dalam mengikuti proses belajar mengajar sesuai dengan tujuan pendidikan yang ditetapkan. Tahapan-tahapan dalam model pembelajaran Problem Based Learningdengan Multimedia tersebut dapat berpotensi dalam pengembangan kemampuan siswa dalam menyelesaikan masalah dan sekaligus dapat menguasai pengetahuan dan keterampilan yang sesuai dengan tujuan pembelajaran.

3. Apresiasi Siswa

Berdasarkan tabel 1di atas dapat diperoleh persentase rata-rata apresiasi menulis puisi klasikal pada siklus I dan siklus II sebagai berikut.

Rata-rata apresiasi menulis puisi siklus I adalah:

$$
\frac{911}{1280} \times 100 \%=71,17 \%
$$

Rata-rata apresiasi menulis puisi siklus II adalah:

$$
\frac{1072}{1280} \times 100 \%=83,75 \%
$$

Berdasarkan persentase rata-rata apresiasi menulis puisi di atas, penerapan model pembelajaran Problem Based Learning dengan Multimedia dapat meningkatkan apresiasi menulis puisi pada muatan pelajaran bahasa Indonesia khususnya dalam menulis puisi siklus I memperoleh rata-rata apresiasi menulis puisi sebesar $71,17 \%$ dan meningkat pada siklus ll sebesar $83,75 \%$.

4. Pengembangan Pembelajaran 
Berdasarkan hasil wawancara dengan guru dan siswa setelah mengikuti pembelajaran menggunakan model pembelajaran Problem Based Learning dengan Multimedia pada siklus I dan siklus II dapat dikembangkan agar pembelajaran lebih berhasil dan menarik minat belajar siswa dengan pembelajaran yang berbasis apresiatif (penghargaan). Penghargaan ini berwujud pada penghargaan terhadap hasil tulisan siswa dengan segala ciri khas perkembangannya. Mengapresiasi merupakan salah satu cara untuk membangun rasa percaya diri sehingga siswa termotivasi untuk mengembangkan kemampuan dirinya. Hal ini sejalan dengan pendapat Kurniawan (2014: 27), bahwa pembelajaran berbasis apresiasi mendasarkan pada pentingnya apresiasi dalam meningkatkan kemampuan dan budaya menulis bagi siswa. Apresiasi yang dikembangkan adalah apresiasi karya siswa dengan menilai hasil karya siswa di hadapan siswa yang lain dan apresiasi dengan mengirimkan karya kreatif siswa dalam menulis puisi ke media massa dan penerbit. Dengan dua pengembangan apresiasi menulis puisi ini siswa akan semakin termotivasi menulis karena ingin karyanya dinikmati teman-temannya dan dimuat serta diterbitkan oleh media massa dan penerbit.

\section{B. Hasil Belajar Penerapan Model Pembelajaran Problem Based Learning Dengan Multimedia Dalam Pembelajaran Menulis Puisi}

Perubahan perilaku dalam belajar mencakup seluruh aspek pribadi siswa yaitu aspek kognitif, afektif, dan psikomotor sebagaimana hasil belajar berikut ini.

1. Prestasi Belajar: $80 \%$ Siswa Mendapat Nilai $\geq 75$

Pada siklus I dicapai jumlah siswa yang tuntas belajar dengan KBM (Ketuntasan Belajar Minimal) 75 adalah dengan persentase siswa yang tuntas belajar $71,88 \%$. Pada siklus II dicapai jumlah siswa yang tuntas belajar dengan persentase siswa yang tuntas belajar $87,50 \%$. Dengan persentase ketuntasan belajar sebesar $87,50 \%$ maka secara kelompok kelas tersebut dinyatakan tuntas. Suatu kelas dinyatakan telah tuntas belajar bila di kelas tersebut telah terdapat $80 \%$ siswa yang telah tuntas.

2. $80 \%$ Siswa Mampu Menghasilkan Puisi Dengan Kualifikasi Baik

Dari data hasil puisi siswa siklus I, diperoleh kualifikasi melalui persentase ketuntasan siswa dalam satu kelas (klasikal) sebesar $71,88 \%$, maka dinyatakan kelas tersebut belum mampu menghasilkan puisi dengan kualifikasi baik. Pada siklus II diperoleh kualifikasi melalui persentase ketuntasan siswa dalam satu kelas (klasikal) sebesar $87,50 \%$, maka dinyatakan kelas tersebut mampu menghasilkan puisi dengan kualifikasi baik.

3. $80 \%$ Siswa Memiliki Tingkat Keaktifan Belajar Baik

Indikator yang digunakan untuk mengukur peningkatan aspek psikomotor siswa diamati saat pembelajaran berlangsung terdiri dari 5 fase pembelajaran. Berdasarkan tabel keaktifan belajar siswa dalam penerapan model pembelajaran Problem Based Learning dengan Multimedia pada muatan pelajaran bahasa Indonesia khususnya dalam menulis puisi siklus I ini memperoleh rata-rata keaktifan kelas sebesar $77,25 \%$, maka siswa belum mencapai keaktifan belajar yang baik. Pada siklus II diperoleh rata-rata keaktifan kelas sebesar 85,25\%, maka siswa sudah memiliki tingkat keaktifan belajar yang baik. 
4. $80 \%$ siswa Memiliki Apresiasi Menulis Puisi Baik

Indikator yang digunakan untuk mengukur peningkatan aspek afektif siswa diamati dengan memberikan angket apresiasi dalam pembelajaran menulis puisi. Berdasarkan tabel 1 diperoleh persentase rata-rata apresiasi menulis puisi setelahpenerapan model pembelajaran Problem Based Learning dengan Multimedia pada mata pelajaran bahasa Indonesia khususnya dalam menulis puisi siklus I ini sebesar $71,17 \%$ danpersentase rata-rata apresiasi menulis puisi setelahpenerapan model pembelajaran Problem Based Learning dengan Multimedia pada mata pelajaran bahasa Indonesia khususnya dalam menulis puisi siklusll ini sebesar $83,75 \%$.

Penerapan model Problem Based Learning dengan Multimedia pada siklus II tersebut, dinyatakan sudah meningkatkan aspek afektif siswa pada mata pelajaran bahasa Indonesia khususnya kemampuan menulis puisi, karena83,75\% siswa memperoleh nilai dengan kriteria baik. Hasil belajar merupakan perubahan perilaku yang menghasilkan kualifikasi baik dalam belajar yang mencakup seluruh aspek pribadi siswa yaitu aspek kognitif, afektif dan psikomotor. Hal ini sejalan dengan pendapat Susanto (2013: 5), bahwa hasil belajar adalah perubahan yang terjadi pada diri siswa, baik yang menyangkut aspek kognitif, afektif, dan psikomotor.

Penerapan model pembelajaran Problem Based Learning dengan Multimedia mampu menghasilkan puisi dengan kualifikasi baik yang ditunjukkan pada siklus II diperoleh kualifikasi melalui persentase ketuntasan siswa dalam satu kelas (klasikal) sebesar $87,50 \%$. Hal ini sejalan dengan penelitian yang telah dilakukan oleh Sabrina (2017: 280), yang menunjukkan bahwa penggunaan Keterampilan menulis teks puisi siswa kelas VIII SMP Negeri 31 Padang sesudah menggunakan model PBL berbantuan media audiovisual berada pada kualifikasi baik (B) dengan rata-rata 82,06.Penulis mengawali cerita pada novel Negeri 5 Menara dengan mengenalkan tokoh-tokoh yang terlibat dalam novel. Tokoh yang muncul di awal adalah tokoh Alif, Amak, Ayah, dan juga tokoh lain yang mendukung perkenalan awal. Selain itu, penulis menyampaikan pandangan awal tentang sekolah agama secara umum yang selama ini banyak berkembang di masyarakat. Di bagian ini penulis belum begitu banyak membuka wacana tentang pendidikan pesantren. Penulis lebih banyak menyoroti tentang perbedaan sekolah umum dan sekolah agama dalam pandangan masyarakat yang direpresentasikan melalui tokoh Alif. Alif menganggap dengan sekolah di pesantren maka tidak akan dapat meraih cita-cita. Berdasarkan hasil penelitian, penggambaran tokoh Alif di awal cerita merupakan tokoh yang penuh keragu-raguan, ketidakpercayaan, serta keputusasaan karena cita-citanya yang selama ini dibangun runtuh seketika hanya karena perbedaan pandangannya dan pandangan orang tuanya mengenai pendidikan. Hal ini disebabkan orang tua Alif tidak setuju jika Alif mendaftar SMA selepas dari pendidikan tsanawiyah. Orang tua Alif lebih mengingingkan Alif untuk melanjutkan pendidikannya di Aliyah. Namun, pada bagian selanjutnya dijelaskan bahwa Alif lebih memilih melanjutkan pendidikannya di sebuah pondok di Jawa meski dengan setengah hati.

\section{Kesimpulan}


Penerapan model pembelajaran Problem Based Learning dengan Multimedia dapat meningkatkan aktifitas dan apresiasi dalam menulis puisi siswa kelas VIII G SMP Negeri 1 Pangkur Kecamatan Pangkur Kabupaten Ngawi. Model pembelajaran Problem Based Learning dengan Multimedia dapat meningkatkan hasil belajar menulis puisi siswa kelas VIII G SMP Negeri 1 Pangkur Kecamatan Pangkur Kabupaten Ngawi yang mencakup seluruh aspek pribadi siswa yaitu aspek kognitif, afektif, dan psikomotor.

\section{Daftar Pustaka}

Hamalik, O. (2004). Proses Belajar Mengajar. Jakarta: Bumi Aksara.

Ivers, Karen S. \& Barron, Ann E. (2010). Multimedia Projects in Education: Designing, Producing, And Assessing. ABC-CLIO, LLC: California.

Kurniawan, H. (2014). Pembelajaran Menulis Kreatif Berbasis Komunikatif dan Apresiatif. Bandung: PT Remaja Rosdakarya.

Ngalimun, dkk. (2016). Strategi dan Model Pembelajaran. Yogyakarta: Aswaja Pressindo.

Suhana, C. (2014). Konsep Strategi Pembelajaran. Bandung: PT Refika aditama.

Sabrina, R. M. (2017). Pengaruh Model Problem Based Learning Berbantuan Media Audiovisual Terhadap Keterampilan Menulis Teks Puisi Siswa Kelas VIII SMP Negeri 31 Padang. Jurnal Pendidikan Bahasa dan Sastra Indonesia, Vol. 6 No. 2 September 2017; seri C 272-280, diunduh 16 Juli 2018.

Sanjaya, W. (2009). Penelitian Tindakan Kelas. Jakarta: Kencana.

Tarigan, H. G. (2008). Menulis Sebagai Suatu Keterampilan Berbahasa. Bandung: Angkasa.

Uno, H. B. \& Mohamad, N. (2015). Belajar dengan Pendekatan PAILKEM. Jakarta: PT Bumi Aksara.

Waluyo, H. J. (1995). Teori dan apresiasi Puisi. Jakarta: Penerbit Erlangga. 